\title{
Static balance of elderly women submitted to a physical activity program
}

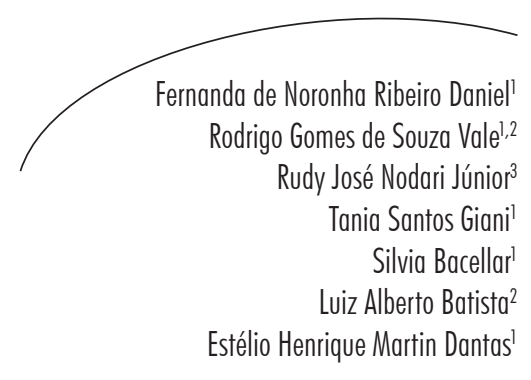

\section{Abstract}

Objective: The aim of this study was to determine the effects of a physical activity program on static balance in elderly women. Method: The sample was randomly subdivided into an experimental group $(\mathrm{EG} ; \mathrm{n}=28 ; 65.64 \pm 2.36$ years; $\mathrm{BMI}=27.52 \pm 3.13)$ and a control group $(C G ; n=21 ; 66.84 \pm 2.31$ years; $B M I=27.67 \pm 2.78)$. The $E G$ participated in twiceweekly 60 -minute sessions of physical activity for 12 weeks, with a perceived intensity level between 3 and 5 (CR10 scale). Static balance was evaluated using a baropodometric platform. Mean postural amplitude oscillations were measured in displacement from the center of pressure (COP), left lateral (LLD), right lateral (RLD), anterior (AD) posterior (PD) and elliptical (EA) area. Results: Repeated-measures analysis of variance showed a significant decrease in EG pre and post-test oscillations $(p<0.05)$ in the COP, AD $(\Delta=0.59 ; p=0.021), \mathrm{PD}(\Delta=-0.91 ; p=0.001)$ and $\mathrm{EA}(\Delta=1.56 ; p=0.044)$ displacement. When comparing the groups, post-test amplitude oscillations in the COP, RLD $(\Delta \%=-7.40$; $p=0.006), \mathrm{AD}(\Delta \%=-30.63 ; p=0.007), \mathrm{PD}(\Delta \%=-42.96 ; p<0.001)$ and $\mathrm{EA}(\Delta \%=-34.41$; $p=0.017)$ of the EG were significantly lower $(p<0.05)$ than those of the CG. There were no significant LLD alterations. Conclusion: The results confirm that static balance improved with physical exercise in EG subjects.

\footnotetext{
Universidade Federal do Estado do Rio de Janeiro, Laboratório de Biociências da Motricidade Humana. Rio de Janeiro, RJ, Brasil.

2 Universidade do Estado do Rio de Janeiro, Centro de Educação e Humanidades, Instituto de Educação Física e Desportos, Programa de Pós-graduação em Ciências do Exercício e do Esporte. Rio de Janeiro, RJ, Brasil.

3 Universidade do Oeste de Santa Catarina, Programa de Pós-graduação em Biociências e Saúde. Joaçaba, SC, Brasil.
}

Key words: Aging; Balance; Exercise; Physical Activity. 


\section{INTRODUCTION}

Ageing is a natural phenomenon involving biological, environmental and psychological factors. ${ }^{1}$ Significant changes occur in cell, tissue and organ activity and physiological processes become less efficient. ${ }^{2}$ The neuromuscular system declines and strength, muscle mass and joint mobility decreases. ${ }^{3-5}$

These factors can influence coordination and control of static and dynamic balance, ${ }^{6-8}$ which, in turn, reduces postural stability. These results in gait deviation, instability, nausea and frequent falls. ${ }^{9-11}$ These falls are often the most dangerous consequences of imbalance and movement difficulties and account for $70 \%$ of accidental deaths in people over $75 .{ }^{12}$

Maintaining balance for posture control requires the interaction of different sensory information systems (visual, vestibular and somatosensory), the active and passive properties of the musculoskeletal system and part of the nervous system. ${ }^{13-17}$ Postural control maintains the body's center of gravity at the base of support. Weight is displaced quickly and precisely from the center in different directions. The individual achieves coordinated movement safely and quickly and can adapt to external instabilities. ${ }^{16,18,19}$

Deterioration in several systems can influence postural control. This affects gait and causes postural instability and falls., ${ }^{911}$ Stimulation of the neuromuscular system is essential to maintain balance, since the correct performance of this system is necessary to carry out activities of daily living. ${ }^{720-23}$ In this sense, among the other physical qualities necessary for healthy aging, loss of balance is a constant concern in aging due to the possibility of falls with advancing age, which can lead to consequences such as physical dependence, reduced quality of life and health of the elderly and higher government spending. Regular exercise can improve the balance of elderly individuals by increasing muscle strength ${ }^{5}$ and flexibility ${ }^{6}$ and improved functional mobility and postural stability. ${ }^{16,20,22}$ The participation of elderly subjects in physical activity programs can be an effective strategy for improving balance and postural control, which can prevent falls and the decline of the performance of activities of daily living among elderly persons.

Thus, the aim of the present study was to analyze the effects of a physical activity program on static balance among elderly women.

\section{METHOD}

\section{Sample}

An experimental study was performed of a population of 350 elderly individuals from the Programa de Saúde da Família (Family Health Program) (PSF08) in Piçarreira I, in the city of Teresina, state of Piauí, Brazil, in 2009 and 2010. All participants were women aged 60 years or older, independent in activities of daily living (ADL) who had not participated in systematic physical activity for at least six months before the study. The women underwent medical evaluation to confirm their eligibility for the study and test protocols.

Exclusion criteria were: (1) elderly women with neurological or vestibular disorders (2) movement disorders related to cognitive decline and (3) those using balance-compromising medication.

Fifty-six women were selected and randomly subdivided by a simple draw into an experimental and a control group with 28 subjects in each. Seven subjects from the control group, however, withdrew from the study. Thus, the study was composed of an experimental group (EG; $n=28$; age $=65.64 \pm 2.36$ years; height $=1.51 \pm 5.78 \mathrm{~m}$; weight $=63.01 \pm 4.36 \mathrm{~kg} ; \mathrm{BMI}=27.52 \pm 3.13)$ and a control group (CG; $\mathrm{n}=21$; age $=66.84 \pm 2.31$ years; height $=1.54 \pm 6.21 \mathrm{~m}$; weight $=65.62 \pm 5.27 \mathrm{~kg}$; $\mathrm{BMI}=27.67 \pm 2.78)$.

The subjects had educational levels of primary school $(35 \%)$ and middle school (65\%), with a family income of up to three minimum salaries. 
There were no smokers in the study. Only three subjects had type 2 diabetes mellitus. The subjects had normal blood pressure and no history of falling in the previous year. There were no significant differences between groups for these characteristics.

All the participants signed a free and informed consent form as per the Declaration of Helsinki. ${ }^{24}$ In addition, the study followed Brazilian National Health Council resolution 196/1996. The study was approved by the Human Research Ethics Committee of the Universidade do Estado do Piauí, Faculdade de Ciências Médicas (protocol number 89/08).

\section{Data collection}

\section{Anthropometric evaluation}

Height and body weight were determined using a mechanical scale with a $150 \mathrm{~kg}$ capacity and accuracy of $100 \mathrm{~g}$ and a Filizola (Brazil) stadiometer. Both evaluations were in accordance with the International Society for the Advancement of Kinanthropometry ${ }^{25}$ protocols.

\section{Balance assessment}

Balance was assessed at the beginning and end of the study using an $\mathrm{AM}^{3}$ Foot Work Pro (Italy) electronic baropodomoter, which contains 4096 polycarbonate-coated sensors measuring $645 \times 520 \times 25 \mathrm{~mm}$. Its calibration was performed using the Balance Clinic (USA). The platform has sensors connected to a computer interface that analyze body sway and assess the projection of center of gravity forces onto the support base. Thus, these sensors are intended to measure and compare displacements in different points of the plantar region, and small fluctuations arising from changes in postural tone every time the correction of balance occurs. ${ }^{9,13,16,26}$ This effectively means measuring the body's ability to remain stable..$^{22,27}$ Testing was carried out in a quiet setting in the morning, at $200 \mathrm{~Hz}$ and temperatures between 23 and $25^{\circ} \mathrm{C}$. Participants remained seated and at rest for five minutes before the test. Static balance was measured only with eyes open. ${ }^{13}$ The subjects were placed barefoot onto the platform in an orthostatic bipodal position with their arms at their sides and asked to focus on a target $90 \mathrm{~cm}$ away, with their heels two centimeters apart and feet at $30^{\circ}$. The position was held for 20 seconds, and data was only recorded after 10 seconds in the position. ${ }^{28}$ Mean amplitudes were measured at the center of pressure (COP) and frontal plane of right (RLD) and left (LLD) lateral displacement, in the sagittal plane of anterior (AD) and posterior (PD) displacement and in the elliptical area (AE) formed by the displacement of the body's center of gravity (COG) on the flat platform.

\section{Physical activity program}

The physical activity program was composed of: 1: a 10-minute warm-up period of stretching exercises at submaximal level for the main joints; 2: a 20 minute walk; 3: 15 minutes of large muscle group exercises ( 2 sets of 15 repetitions: squats, elbow and knee flexions and extensions, horizontal shoulder flexions and extensions, foot flexions and stomach crunches); 4: 10 minutes of static stretching exercises at maximum movement amplitude; 5: a 5 minute rest period.

Participants controlled their exercise intensity according to their perceived effort, ${ }^{29}$ at a moderate level on the CR10 scale (level 3 to 5). The duration of the physical activity program was 12 weeks, with two weekly 60 -minute sessions.

\section{Statistical analysis}

Data was processed with the SPSS 14.0 program for Windows and shown as mean, standard deviation and percentage differences $(\Delta \%)$. The ShapiroWilk and Levene tests were used to determine the normality and homogeneity of variable data 
in the sample groups. Repeated-measures analysis of variance (group and time factors) was used for intra and inter-group comparison, followed by the Tukey post hoc test to identify possible differences. The statistical significance value in this study was $p<0.05$.

\section{RESULTS}

Repeated measures ANOVA found an interaction between the groups and the time of the measurements (Wilks' Lambda $=0.527, \mathrm{~F}=4.532$, $p<0.001)$. The power of the experiment presented RLD, LLD, AD, PD and EA values of $92 \%, 26 \%$, $96 \%, 99 \%$ and $90 \%$, respectively, strengthening the magnitude of the results achieved in the analysis of the balance of the sample.
Table 1 shows the results of intra and intergroup comparison for variables related to balance. The EG showed a significant decrease in pre and post-test COP displacement in the $\operatorname{AD}(\Delta=0.59 \mathrm{~cm} ; p=0.020), \operatorname{PD}(\Delta=-0.91 \mathrm{~cm}$; $p<0.001)$ and the EA $\left(\Delta=1.56 \mathrm{~cm}^{2} ; p=0.044\right)$. This was not true for lateral displacement. The CG showed no significant intragroup alterations. Intergroup comparison showed that COP amplitude displacement in the EG were significantly lower $(p<0.05)$ in the RLD $(\Delta \%=$ $7.40 \% ; p=0.006), \mathrm{AD}(\Delta \%=-30.63 \% ; p=0.007)$, PD $(\Delta \%=-42.96 \% ; p<0.001)$ and EA $(\Delta \%=-$ $34.41 \%$; $p=0.017)$ when compared with the CG in post-test analysis. The COP oscillations in the LLD showed no significant alterations. These intergroup results are confirmed in figure 1 by percentage difference $(\Delta \%)$ comparisons.

Table 1. Results of postural oscillation in center of pressure (COP) displacement for experimental group (EG) and control group (CG) from the Programa de Saúde da Família (Family Health Program) (PSF08). Teresina, Piauí, 2009 and 2010.

\begin{tabular}{lccc}
\hline Group & Variables & Mean \pm SD (pre) & Mean \pm SD (post) \\
\hline EG & RLD $(\mathrm{cm})$ & $1.15 \pm 0.31$ & $1.07 \pm 0.33 \#$ \\
& LLD $(\mathrm{cm})$ & $-1.12 \pm 0.43$ & $-1.16 \pm 0.34$ \\
& AD $(\mathrm{cm})$ & $1.93 \pm 0.76$ & $1.34 \pm 0.66^{*} \#$ \\
& PD (cm) & $-2.11 \pm 0.75$ & $-1.20 \pm 0.37 * \#$ \\
& EA $\left(\mathrm{cm}^{2}\right)$ & $4.53 \pm 2.42$ & $2.97 \pm 1.37 * \#$ \\
CG & RLD (cm) & $1.32 \pm 0.43$ & $1.44 \pm 0.36$ \\
& LLD (cm) & $-1.28 \pm 0.41$ & $-1.27 \pm 0.39$ \\
& AD $(\mathrm{cm})$ & $2.04 \pm 0.80$ & $2.11 \pm 0.76$ \\
& PD $(\mathrm{cm})$ & $-2.24 \pm 0.91$ & $-2.17 \pm 0.90$ \\
& EA $\left(\mathrm{cm}^{2}\right)$ & $4.73 \pm 2.50$ & $5.01 \pm 2.36$ \\
\hline
\end{tabular}

$\mathrm{SD}=$ standard deviation; $\mathrm{RLD}=$ right lateral $\mathrm{LLD}=$ left lateral; $\mathrm{AD}=$ anterior; $\mathrm{PD}=$ posterior; $\mathrm{EA}=$ elliptical area; $* p<0.05=$ statistically significant difference of intra-group comparison; $\# p<0.05=$ statistically significant difference of intergroup comparison. 




Figure 1. Percentage difference $(\Delta \%)$ of center of pressure (COP) oscillations in right lateral (RLD), left lateral (LLD), anterior (AD), posterior (PD) and elliptical area (EA) displacement in the experimental (EG) and control groups (CG) from the Programa de Saúde da Família (PSF08) (Family Health Program). Teresina, Piauí, 2009 and 2010.

\section{DISCUSSION}

The findings of the present study show a significant decrease in mean COP amplitudes for RLD, AD, PD and EA displacement in the EG when compared with the CG. This suggests that the physical activity program (PAP) improved balance in the elderly women studied when analysis was performed by traditional approach and that a decrease in stabilometric variables is related to improvements in postural balance. ${ }^{9,16,27,30}$

The duration of the physical activity program in this study caused positive balance responses in the EG. Mann et al. ${ }^{30}$ compared the balance of elderly subjects practicing hydro-gymnastics for a period of $1-5$ years with middle-aged sedentary adults, using a baropodometric platform for 10 seconds. Elderly females showed better results $(p<0.05)$ than sedentary women in mid-lateral COP displacement. This corroborates in part with the results of the present study, which also found balance improvement in the EG in the sagittal plane (AD and PD). However, differences between the two studies may be due to the different age groups used in the control samples.

Carvalho et al. ${ }^{31}$ compared the balance of elderly subjects who exercised regularly $(\mathrm{n}=28$, age $=77.1 \pm 7.2$ years) with sedentary subjects $(\mathrm{n}=28$, 
age $=79.4 \pm 8.1$ years) and found higher values for the active group in Tinetti's Performance-Oriented Mobility Assessment of gait and balance (POMA) tests $(p<0.001)$. This corresponds with the results of the present study, although different balance evaluation techniques were used. In the POMA test a better result is represented by a higher value. However, when using a baropodometric platform, a lower value indicates less COP displacement and therefore better postural stability and balance. This confirms that elderly people who exercise regularly have better balance than those who are sedentary.

Abreu \& Caldas ${ }^{32}$ used the Berg and POMA tests to study the effects of a general therapeutic exercise program on elderly subjects. The results showed that the balance indicators of the group participating in therapeutic exercise improved when compared with the control group. This confirms the findings for the EG in the present study. The general exercise program caused improvements in the elderly subjects in the same way as the therapeutic exercises, although the variable evaluation methods were different. However, subjects in this age group may maintain balance control for longer when they exercise regularly.

Rugelj ${ }^{16}$ evaluated the balance and performance of elderly subjects in 14 functional activities, using the 10 meter walk test. Stabilometry found no significant improvement in the experimental group for COP displacement in the frontal and sagittal planes and elliptical area. However, subjects did show an improvement in walking. These results contrast with those of the present study owing to the different exercises used in the physical activity programs. Isotalo et al. ${ }^{13}$ report that various body movements can create stimulants and distinct sensory information, causing positive adaptations in the sensory motor system. The different PAP exercises may therefore have contributed to the positive balance results in the EG.

Exercise intensity controlled by participant effort perception (CR10 level 3 - 5) stimulated positive balance results in the EG using a baropodometric platform. However, Zak et al. ${ }^{23}$ used the POMA test to evaluate elderly subjects in a multiple exercise program. The high-intensity program, which included progressive loads, functional orientations and nutritional control, achieved significant improvements in balance control. This suggests that oriented moderateintensity exercise may improve balance in the elderly when practiced regularly and systematically.

In this study, pre-test results in the EG and pre and post-test results in the CG revealed higher COP posterior oscillations. However, post-test EG mean COP anterior displacement was greater than mid-posterior displacement. This corroborates the findings of Aikawa et al., ${ }^{27}$ who evaluated COP postural oscillation in two different elderly age groups. Posterior postural oscillations were higher in both groups (60 to 70 years and 71 to 80 years), a common finding in the elderly. These oscillations are related to changes in the support base or unexpected displacement such as joint instability, ${ }^{33}$ weak muscles ${ }^{22}$ and high BMI as more displacement is needed to maintain postural balance. ${ }^{34}$ However, these considerations are limited because the associations were not studied. Another limitation of the present study was that an image analysis tool, such as cinemetry, was not used to check for any changes in the posture of the study sample.

\section{CONCLUSION}

The present study found a decrease in center of pressure displacement in the sagittal plane and elliptical area that significantly improved static balance in the experimental group. This suggests that the physical activity program examined in this study may contribute to maintaining postural control in the elderly, supporting future research on balance in relation to other variables such as falls, fear of falls and self-confidence during ageing. 


\section{REFERENCES}

1. Moran S, Chen Y, Ruthie A, Nir Y. Alterations in IGF-1 affect elderly: role of physical activity. Eur Rev Aging Phys Act 2007;4:77-84.

2. Gibney J, Healy ML, Sönksen PH. The growth hormone/insulin-like growth factor-1 axis in exercise and sport. Endocr Rev 2007;28:603-24.

3. Sacco ICN, Bacarin TA, Watari R, Suda EY, Canettieri MG, Souza LC, et al. Envelhecimento, atividade física, massa corporal e arco plantar longitudinal influenciam no equilíbrio funcional de idosos? Rev Bras Educ Fís Esp 2008;22(3):183-91.

4. Shiga T, Tsuji Y, Fujioka M, Kubo T. Risk factors for hip fracture in Japanese elderly women with osteoporosis: applicability of biochemical markers in bone turnover. Geriatr Gerontol Int 2009;9(1):69-74.

5. Vale RGS, Oliveira RD, Pernambuco CS, Meneses YPSF, Novaes JS, Andrade AFD. Effects of muscle strength and aerobic training on basal serum levels of IGF-1 and cortisol in elderly women. Arch Gerontol Geriatr 2009;49(3):343-47.

6. Rebelato JR, Calvo JI, Orejuela JR, Portillo JC. A influência de um programa de atividade física de longa duração sobre a força muscular manual e a flexibilidade corporal de mulheres idosas. Rev Bras Fisioter 2006;10(1):107-32.

7. Salminen M, Vahlberg T, Sihvonen S, Sjösten N, Piirtola M, Isoaho R, et al. Effects of risk-based multifactorial fall prevention on postural balance in the community-dwelling aged: a randomized controlled trial. Arch Gerontol Geriatr 2009;48(1):22-7.

8. Chiba H, Ebihara S, Tomita N, Sasaki H, Butler JP. Differential gait kinematics between fallers and nonfallers in community-dwelling elderly people. Geriatr Gerontol Int 2005;5(2):127-34.

9. Baraúna MA, Barbosa SRM, Canto RST, Silva RAV, Silva CDC, Baraúna KMP. Estudo do equilíbrio estático de idosos e sua correlação com quedas. Rev Fisioter Brasil 2004;5(2):136-41.

10. Aslan UB, Cavlak U, Yagci N, Akdag B. Balance performance, aging and falling: a comparative study based on a Turkish sample. Arch Gerontol Geriatr 2008;46(3):283-92.

11. Tainaka K, Takizawa T, Katamoto S, Aoki J. Six-year prospective study of physical fitness and incidence of disability among community-dwelling Japanese elderly women. Geriatr Gerontol Int 2009;9(1):21-8.
12. Ruwer SL, Rossi AC, Simon LF. Equilíbrio no idoso. Rev Bras Otorrinolaringol 2005;71(3):298-303.

13. Isotalo E, Kapoula Z, Feret PH, Gauchonc K, Zamfirescu F, Gagey PM. Monocular versus binocular vision in postural control. Auris Nasus Larynx 2004;31(1):11-7.

14. Bastos AGD, Lima MAMT, Oliveira LF. Avaliação de pacientes com queixa de tontura e eletronistagmografia normal por meio da estabilometria. Rev Bras Otorrinolaringol 2005;71(3):305-10.

15. Jbabdi M, Boissy P, Hamel M. Assessing control of postural stability in community-living older adults using performance-based limits of stability. BMC Geriatrics 2008;8(8):1-10.

16. Rugelj D. The effect of functional balance training in frail nursing home residents. Arch Gerontol Geriatr 2009;50(2):192-7.

17. Vassallo M, Mallela SK, Williams A, Kwan J, Allen $\mathrm{S}$, Sharma JC. Fall risk factors in elderly patients with cognitive impairment on rehabilitation wards. Geriatr Gerontol Int 2009;9(1):41-6.

18. Ragnarsdóttir M. The concept of balance. Phys Ther 1996;82(6):368-75.

19. Gazzola JM, Muchale SM, Perracine MR, Cordeiro RC, Ramos LR. Caracterização funcional do equilíbrio de idosos em serviço de reabilitação gerontológica. Rev Fisioter Univ São Paulo 2004;11(1):1-14.

20. Ribeiro F, Teixeira F, Brochado G, Oliveira J. Impact of low cost strength training of dorsi- and plantar flexors on balance and functional mobility in institutionalized elderly people. Geriatr Gerontol Int 2009;9(1):75-80

21. Sakamoto Y, Ueki S, Kasai T, Takato J, Shimanuki $\mathrm{H}$, Honda $\mathrm{H}$, et al. Effect of exercise, aging and functional capacity on acute secretory immunoglobulin, a response in elderly people over 75 years of age. Geriatr Gerontol Int 2009;9(1):81-8.

22. Wiacek M, Hagner W, Hagner-Derengowska M, Blujc B, Drozdc M, Czerebac J, et al. Correlations between postural stability and strength of lower body extremities of women population living in long-term care facilities. Arch Gerontol Geriatr 2009;48(3):346-9. 
23. Zak M, Swine C, Grodzicki T. Combined effects of functionally-oriented exercise regimens and nutritional supplementation on both the institutionalised and free-living frail elderly (doubleblind, randomised clinical trial). BMC Public Health 2009; 9(39):1-15.

24. World Medical Association. Declaration of Helsinki: ethical principles for medical research involving human subjects. Geneva: WMA; 2008.

25. Marfell-Jones M, Olds T, Stewart A, Carter L. International standards for anthropometric assessment. Potchefstroom: ISAK ; 2006.

26. Ishiazaki K, Mori N, Takeshima T, Fukuhara Y, Ijiri T, Kusumi M, et al. Static stabilometry in patients with migraine and tension-type headache during a headache-free period. Psychiatry Clin Neurosci 2002;56(1):85-90.

27. Aikawa AC, Braccialli LMP, Padula RS. Efeitos das alterações posturais e de equilíbrio estático nas quedas de idosos institucionalizados. Rev Ciênc Med 2006;15(3):189-96.

28. Scoppa F, Capra R, Gallamini M, Shiffer R. Clinical stabilometry standar- dization: basic definitions, acquisition interval, sampling frequency. Gait Posture 2013;37(2):290-2.

29. Borg GAV. Physiological bases of perceived exertion. Med Sci Sports Exerc 1982;14(3):377-87.

30. Mann L, Kleinpaul JF, Teixeira CS, Rossi AG, Lopes LFD, Mota CB. Investigação do equilíbrio corporal em idosos. Rev Bras Geriatr Gerontol 2008;11(2):155-65.

31. Carvalho J, Pinto J, Mota J. Actividade física, equilíbrio e medo de cair: um estudo em idosos institucionalizados. Rev Port Ciênc Desporto 2007;7(2):225-31.

32. Abreu SSE, Caldas CP. Velocidade de marcha, equilíbrio e idade: um estudo correlacional entre idosas praticantes e idosas não praticantes de um programa de exercícios terapêuticos. Rev Bras Fisioter 2008;12(4):324-30.

33. Perracine MR, Ramos LR. Fatores associadas às quedas em um corte de idosos residentes na comunidade. Rev Saúde Pública 2002;36(6):709-16.

34. Greve J, Alonso A, Bordini ACPG, Camanho GL. Correlação entre índice de massa corpórea e equilíbrio postural. Clinics 2007;62(6):717-20. 